www.jmscr.igmpublication.org Impact Factor 5.244

Index Copernicus Value: 83.27

ISSN (e)-2347-176x ISSN (p) 2455-0450

crossref DOI: http://dx.doi.org/10.18535/jmscr/v4i7.01

Journal Of Medical Science And Clinical Research

\title{
Serum Calprotectin as a Non-invasive Diagnostic Marker for Spontaneous Bacterial Peritonitis in Egyptian Cirrhotic Patients
}

\author{
Authors \\ Amir Helmy ${ }^{1}$, Ahmed El Saady Khayyal ${ }^{1}$, Sara M Abdelhakam², Shereen A Saleh ${ }^{1}$, \\ Hesham Abouellail ${ }^{1}$, Sameh Abdelraouf ${ }^{1}$, Abdel Rahman Esam ${ }^{1}$, Marwa Rushdy ${ }^{3}$ \\ ${ }^{1}$ Department of Internal Medicine, Faculty of Medicine, Ain Shams University, Cairo, Egypt \\ ${ }^{2}$ Department of Tropical Medicine, Faculty of Medicine, Ain Shams University, Cairo, Egypt \\ ${ }^{3}$ Department of Clinical and Chemical Pathology, Faculty of Medicine, Ain Shams University, Cairo, Egypt \\ *Corresponding Author \\ Sara M Abdelhakam, MD \\ Assistant Professor of Tropical Medicine, Department of Tropical Medicine, \\ Faculty of Medicine, Ain Shams University, Abbassia, Cairo, Egypt. \\ Email: saratropical@yahoo.com, Telephone: (+2)01001601548
}

\begin{abstract}
BACKGROUND and AIM: Delayed diagnosis of spontaneous bacterial peritonitis (SBP) is associated with high mortality in cirrhotic patients. Therefore, there is a need for a rapid non-invasive diagnostic tool. This work aimed at evaluating the role of serum calprotectin as a non-invasive diagnostic marker for SBP in comparison to $C$-reactive protein (CRP).

METHODS: 75 cirrhotic patients were included and divided into three groups. Group A: 25 patients with cirrhotic ascites and SBP diagnosed by presence of PMNL $\geq 250 / \mathrm{mm}^{3}$ in ascitic fluid with or without positive ascitic fluid culture. Group B: 25 patients with cirrhotic ascites without SBP. Group C: 25 cirrhotic patients with no clinical or ultrasound evidence of ascites as a control group. All were subjected to complete clinical evaluation, routine laboratory investigations, serum calprotectin, CRP levels and diagnostic abdominal paracentesis (only for group A and B).

RESULTS: Group A showed significantly higher levels of ascitic fluid total leukocytic count, polymorphonuclear leukocytes and total protein $(P<0.001)$ in comparison to Group B. Group A had significantly higher serum calprotectin and CRP levels than other groups. There were significant positive correlations between serum calprotectin and serum WBC, CRP and ascitic fluid TLC, PMNL and total protein among group A. Serum calprotectin and CRP had the most significant diagnostic performance in detection of SBP (AUC $=0.976$ and 1.000 respectively, $P<0.001)$. A cut-off level of serum calprotectin $\geq 46.0 \mu \mathrm{g} / \mathrm{mL}$ showed a sensitivity of $100 \%$, specificity $92 \%$ and diagnostic accuracy $96 \%$; while that of $C R P \geq 9.0 \mathrm{mg} / \mathrm{dL}$ showed a sensitivity of 100\%, specificity 100\% and diagnostic accuracy $100 \%$.

CONCLUSION: Serum calprotectin in combination with CRP may be useful for non-invasive diagnosis of SBP.

KEY WORDS: Serum calprotectin, Spontaneous bacterial peritonitis, Liver cirrhosis, Ascites
\end{abstract}




\section{INTRODUCTION}

Spontaneous bacterial peritonitis (SBP) is defined as an infection of the ascitic fluid in the absence of visceral perforation or intra-abdominal inflammation such as abscess, acute pancreatitis or cholecystitis ${ }^{(1,2)}$. It is the most frequent infection in patients with liver cirrhosis and ascites with an incidence varying from 10\%-30\% $(3,4)$.

It has been proven that delayed diagnosis of SBP is associated with high mortality. Thus, an accurate biomarker for the early identification of SBP would be of great diagnostic value. Diagnosis of SBP is based on the presence of neutrophils more than $250 / \mathrm{mm}^{3}$ in ascitic fluid ${ }^{(5)}$. Currently, differential cell count is usually performed by a manual method using light microscopy and counting chambers. However, the diagnosis is often delayed when laboratory personnel are not readily available or in the private practice setting where specimens are sent to an offsite laboratory. Alternative methods using automated polymorphonuclear leukocytes (PMNL) counting have been developed but unfortunately, their diagnostic accuracies are limited ${ }^{(6)}$.

Also, the prolonged time of ascitic fluid culture limits its utility for directing antibiotic selection in acute care settings. The culture has also been reported to be negative in approximately $20 \%$ of patients with clinical manifestations suggestive of SBP and an ascitic PMNL count of $>250 / \mathrm{mm}^{3}$, socalled culture-negative neutrocytic ascites (CNNA). On the other hand, a low ascitic PMNL count $\left(<250 / \mathrm{mm}^{3}\right)$ with positive culture can also occur in another SBP variant called monomicrobial non-neutrocytic bacterascites ${ }^{(7)}$.

Calprotectin is an abundant, calcium- and zincbinding protein found mainly in neutrophils ${ }^{(8)}$, and its presence in body fluids is proportional to the influx of neutrophils ${ }^{(9)}$. It is an acute phase inflammatory reaction protein which exerts regulatory, antimicrobial and anti-proliferative functions. It can halt bacterial growth, playing an important role in non-specific immune reactions (10).

A recent study for measurement of ascitic fluid calprotectin by reagent strips as a bed side test for rapid diagnosis of SBP showed high specificity $(83 \%)$ and sensitivity $(100 \%)^{(6)}$. Another study reported a significant correlation between elevated fecal calprotectin level and the occurrence of some complications in cirrhotic patients such as hepatic encephalopathy and SBP ${ }^{(11)}$. However, the role of serum calprotectin in diagnosing SBP remains unexplored.

This work aimed at evaluating the role of serum calprotectin as a non-invasive diagnostic marker for spontaneous bacterial peritonitis in Egyptian cirrhotic patients in comparison to C-reactive protein.

\section{PATIENTS AND METHODS}

This case control study was conducted on 75 cirrhotic patients admitted to Internal Medicine and Tropical Medicine Departments of Ain Shams University Hospital during the period from June 2015 to February 2016. The patients were divided into three groups. Group A included 25 patients with cirrhotic ascites and spontaneous bacterial peritonitis (SBP). They were diagnosed by presence of PMNL more than $250 / \mathrm{mm}^{3}$ in ascitic fluid with or without positive ascitic fluid culture. Group B included 25 patients with cirrhotic ascites without clinical or laboratory evidence of SBP and with ascitic fluid PMNL count less than 250 and negative culture. Group C included 25 cirrhotic patients with no clinical or ultrasound evidence of ascites as a control group.

Informed written consent was obtained from each patient prior to inclusion. The study protocol was approved by the Research Ethical Committee of Faculty of Medicine, Ain Shams University according to the ethical guidelines of the 1975 Declaration of Helsinki.

Patients with secondary causes of peritonitis such as T.B or malignancy; surgical causes of peritonitis such as intra-abdominal abscess, appendicitis, or pancreatitis; history of abdominal 
surgery in the previous 3 months; previous infection or antibiotic usage one month before presentation; hepatocellular carcinoma; portal or splenic vein thrombosis; inflammatory bowel disease; as well as those with diabetes mellitus were excluded.

All included patients were subjected to the following:

1. Complete history taking and thorough clinical examination.

2. Laboratory investigations:

a) Complete Blood Count (CBC): was done on Coulter LH 750 hematology analyzer (Beckman Coulter International SA, Rue Juste-Olivier 22, PO Box 1059, CH - 1260 Nyon, Switzerland).

b) Liver profile: alanine aminotransferase (ALT), aspartate aminotransferase (AST), serum albumin, total and direct bilirubin, alkaline phosphatase, prothrombin time and INR.

c) Renal profile: creatinine and blood urea.

Liver and renal profiles were done on Synchron CX-5 Delta auto-analyzer using its commercially available reagents (Beckman Instruments Inc.; Scientific Instruments, Division, Fullerton, CA 92634, 3100, USA).

d) Viral markers including: $\mathrm{HBsAg}$, $\mathrm{HBcAb} \operatorname{IgM}$ and $\mathrm{IgG}$ and $\mathrm{HCV}$ Ab by third generation ELISA.

e) Serum C-reactive protein (CRP): was quantified by using the latex slide test (semi-quantitative test) according to the manufacturer's (Teco Diagnostics, Anaheim, CA 92807, U.S.A) instructions.

f) Serum calprotectin level: Assay was carried out using a commercially available enzyme-linked immunosorbent assay (ELISA) kit supplied by (Shanghai Sunred Biological Technology Co) with normal assay range: $0.15-40 \mu \mathrm{g} / \mathrm{ml}$. The kit used a double-antibody sandwich enzymelinked immunosorbent assay (ELISA) to assay the level of Human Calprotectin (CALB) in samples. Calprotectin (CALB) was added to monoclonal antibody Enzyme well which was pre-coated with Human Calprotectin monoclonal antibody, after incubation Calprotectin antibodies labeled with biotin, and combined with Streptavidin-HRP were added to form immune complex; after incubation Chromogen Solution A, B added, the color of the liquid changed into the blue, and at the effect of acid, the color finally became yellow. The chroma of color and the concentration of the Human Substance Calprotectin (CALB) of sample were positively correlated.

3. Abdominal ultrasonography: To assess liver size, liver echogenicity, amount of ascites, spleen size, and any focal lesions.

4. Diagnostic abdominal paracentesis (for patients in group $\mathrm{A}$ and $\mathrm{B}$ ): It was performed under ultrasonographic guidance and aseptic condition. Three samples of ascitic fluid, each of ten centimeters, were taken from each patient at time of admission and sent immediately for bacteriological, chemical and pathological examination with assessment of ascitic fluid polymorphonuclear leukocytic count (PMNL), total cell count, ascitic fluid albumin, total protein, lactate dehydrogenase (LDH), glucose and ascitic fluid culture. The sample for culture was inoculated in aerobic blood culture bottles (Egyptian Diagnostic Media, Cairo, Egypt) at the bedside, and then it was incubated for 3 successive days at $37^{\circ} \mathrm{C}$ with daily subculture on blood, MacConkey and chocolate agars. 
5. Serum-ascites albumin gradient (SAAG) was estimated as (serum albumin - ascitic fluid albumin).

\section{Statistical analysis}

Collected data were coded, tabulated, and statistically analyzed using IBM SPSS statistics (Statistical Package for Social Sciences) software version 22. Descriptive statistics such as minimum and maximum of the range, as well as mean $\pm \mathrm{SD}$, were used for quantitative parametric data. Median and inter-quartile ranges were used for quantitative non-parametric data, while number and percentage were used for qualitative data.

Inferential analyses were done for quantitative variables using independent t-test in cases of two independent groups with parametric data. Correlations were done using Pearson Correlation for numerical parametric data, and Spearman Rho test for numerical non- parametric as well as qualitative data. Receiver operating characteristics (ROC) curve was used to evaluate the performance of different tests, and DeLong test was used to compare between the areas under curves (AUCs).

Diagnostic characteristics were calculated as follows:

- Sensitivity $=[$ true positive $/$ (true positive+ false negative) $] \times 100$

- Specificity $=[$ true negative $/$ (true negative + false positive) $] \times 100$

- Positive likelihood ratio $(\mathrm{LR}+)=$ (true positive / false positive) $\times 100$

- Negative likelihood ratio (LR-) = (false negative / true negative) $\times$ 100

- Diagnostic accuracy $=[($ true positive + true negative) / total cases $] \times 100$.

$\mathrm{P}$ value $<0.05$ was considered statistically significant and $\mathrm{P}<$ 0.01 as highly significant.

\section{RESULTS}

The present study was conducted on 75 cirrhotic patients divided into three groups:

Group A included 25 cirrhotic patients with ascites and spontaneous bacterial peritonitis (SBP) at the time of presentation. They were $16(64 \%)$ males and $9(36 \%)$ females. Their mean age was $55.2 \pm 6.9$ years. Twenty three patients had HCV and two patients had HBV infection. Their main clinical presentations were abdominal pain in 22 patients $(88 \%)$, fever in $21(84 \%)$ and jaundice in 10 patients (40\%). Among this group, 19 patients (76\%) had PMNL $>250 / \mathrm{mm}^{3}$ and positive ascitic fluid cultures (i.e. culture-positive SBP); the organisms isolated were Escherichia coli (12 patients), Citrobacter (three patients), Klebsiella (two patients), Acinetobacter (one patient) and Enterococci (one patient). The remaining six patients $(24 \%)$ had PMNL $>250 / \mathrm{mm}^{3}$ without positive bacteriological culture of ascitic fluid (i.e. culture-negative neutrocytic ascites, CNNA).

Group B included 25 cirrhotic patients with ascites with no clinical or laboratory evidence of SBP (sterile cirrhotic ascites). They were 17 $(68 \%)$ males and $8(32 \%)$ females. Their mean age was $54.0 \pm 6.2$ years. Twenty four patients had HCV and one patient had HBV infection.

Group C included 25 cirrhotic patients without ascites. They were $14(56 \%)$ males and 11 (44\%) females. Their mean age was $54.2 \pm 7.3$. All patients of this group were positive for $\mathrm{HCV}$.

There was no significant difference between the three studied groups regarding the age or gender with $P$ value $>0.05$.

Regarding the Child classification among the three studied groups, group A included 23 patients (92\%) with Child score C and 2 patients (8\%) with Child score B. Group B included 19 patients (76\%) with Child score C and 6 patients (24\%) with Child score B. All patients (100\%) of group $\mathrm{C}$ had Child score A. There was statistically significant difference between groups $\mathrm{A}$ and $\mathrm{C}$, and between groups $\mathrm{B}$ and $\mathrm{C}$ regarding the Child score with $\mathrm{P}$ value $<0.05$. 
Table (1) shows comparison between the three studied groups regarding demographic data and laboratory investigations. Group A had significantly high serum total leukocytic count and low platelet count $(\mathrm{P}<0.001)$.

Table (1): Comparison between the three studied groups regarding demographic data and laboratory investigations:

\begin{tabular}{|c|c|c|c|c|c|c|c|}
\hline \multicolumn{2}{|c|}{ Variable } & \multirow{2}{*}{$\begin{array}{c}\text { Group A } \\
(\mathbf{N}=\mathbf{2 5})\end{array}$} & \multirow{2}{*}{$\begin{array}{c}\text { Group B } \\
(\mathbf{N}=\mathbf{2 5})\end{array}$} & \multirow{2}{*}{$\begin{array}{c}\text { Group C } \\
(\mathbf{N}=\mathbf{2 5}) \\
54.2 \pm 7.3\end{array}$} & \multirow{2}{*}{$\begin{array}{c}\mathbf{A} / \mathbf{B} \\
\mathrm{t}=0.647 \\
\mathrm{p}=0.521 \\
\end{array}$} & \multirow{2}{*}{$\begin{array}{c}\mathbf{A} / \mathbf{C} \\
\mathrm{t}=0.497 \\
\mathrm{p}=0.621 \\
\end{array}$} & \multirow{2}{*}{$\begin{array}{c}\mathbf{B} / \mathbf{C} \\
\mathrm{t}=0.104 \\
\mathrm{p}=0.918\end{array}$} \\
\hline Age (years) & Mean \pm SD & & & & & & \\
\hline $\begin{array}{l}\text { Total bilirubin }(0.2- \\
1.2 \mathrm{mg} / \mathrm{dL})\end{array}$ & Mean \pm SD & $3.1 \pm 2.3$ & $2.3 \pm 1.3$ & $1.7 \pm 0.8$ & $\begin{array}{l}\mathrm{t}=1.513 \\
\mathrm{p}=0.137\end{array}$ & $\begin{array}{c}t=2.926 \\
p=0.005^{*}\end{array}$ & $\begin{array}{c}t=2.000 \\
p=0.050 *\end{array}$ \\
\hline ALT $\quad$ (7-40 IU/L) & Mean \pm SD & $46.5 \pm 19.6$ & $50.7 \pm 22.7$ & $49.0 \pm 20.0$ & $\begin{array}{l}\mathrm{t}=0.307 \\
\mathrm{p}=0.760\end{array}$ & $\begin{array}{l}\mathrm{t}=0.888 \\
\mathrm{p}=0.379\end{array}$ & $\begin{array}{l}\mathrm{t}=1.183 \\
\mathrm{p}=0.243\end{array}$ \\
\hline AST (7-37 IU/L) & Mean \pm SD & $51.9 \pm 20.4$ & $53.1 \pm 23.3$ & $52.8 \pm 22.8$ & $\begin{array}{l}\mathrm{t}=0.460 \\
\mathrm{p}=0.648\end{array}$ & $\begin{array}{c}t=2.082 \\
p=0.043 *\end{array}$ & $\begin{array}{l}\mathrm{t}=1.424 \\
\mathrm{p}=0.161\end{array}$ \\
\hline $\begin{array}{l}\text { Serum Albumin } \\
(3.5-5.3 \mathrm{~g} / \mathrm{dL})\end{array}$ & Mean \pm SD & $2.6 \pm 0.2$ & $2.7 \pm 0.4$ & $3.2 \pm 0.3$ & $\begin{array}{l}\mathrm{t}=0.638 \\
\mathrm{p}=0.526\end{array}$ & $\begin{array}{c}\mathrm{t}=11.34 \\
\mathbf{p}<\mathbf{0 . 0 0 1} *\end{array}$ & $\begin{array}{c}t=11.29 \\
\mathbf{p}<\mathbf{0 . 0 0 1 *}\end{array}$ \\
\hline INR & Mean \pm SD & $1.6 \pm 0.3$ & $1.5 \pm 0.5$ & $1.2 \pm 0.1$ & $\begin{array}{l}\mathrm{t}=0.424 \\
\mathrm{p}=0.673\end{array}$ & $\begin{array}{c}\mathrm{t}=8.518 \\
\mathbf{p}<\mathbf{0 . 0 0 1} *\end{array}$ & $\begin{array}{c}t=7.097 \\
\mathbf{p}<\mathbf{0 . 0 0 1} *\end{array}$ \\
\hline HB (g/dL) & Mean \pm SD & $10.1 \pm 1.4$ & $9.7 \pm 1.4$ & $10.1 \pm 1.2$ & $\begin{array}{l}\mathrm{t}=1.073 \\
\mathrm{p}=0.289\end{array}$ & $\begin{array}{l}\mathrm{t}=0.065 \\
\mathrm{p}=0.948\end{array}$ & $\begin{array}{l}\mathrm{t}=1.063 \\
\mathrm{p}=0.293\end{array}$ \\
\hline $\mathrm{WBC}\left(\times 10^{3} / \mu \mathrm{L}\right)$ & Mean \pm SD & $15.3 \pm 3.5$ & $6.8 \pm 2.7$ & $6.5 \pm 2.0$ & $\begin{array}{c}\mathrm{t}=9.742 \\
\mathrm{p}=<\mathbf{0 . 0 0 1} *\end{array}$ & $\begin{array}{c}\mathrm{t}=10.99 \\
\mathrm{p}=<\mathbf{0 . 0 0 1} *\end{array}$ & $\begin{array}{l}\mathrm{t}=0.425 \\
\mathrm{p}=0.673\end{array}$ \\
\hline PLT $\left(\times 10^{3} / \mu \mathrm{L}\right)$ & Mean \pm SD & $77.9 \pm 26.0$ & $153.4 \pm 65.3$ & $189.0 \pm 55.6$ & $\begin{array}{c}\mathrm{t}=5.370 \\
\mathbf{p}<\mathbf{0 . 0 0 1} *\end{array}$ & $\begin{array}{c}\mathrm{t}=9.046 \\
\mathbf{p}<\mathbf{0 . 0 0 1} *\end{array}$ & $\begin{array}{c}t=2.076 \\
p=0.043 *\end{array}$ \\
\hline
\end{tabular}

*Significant, ALT: Alanine aminotransferase, AST: Aspartate aminotransferase, INR: International normalization ratio, HB: Haemoglobin, WBC: White blood cells, PLT: Platelets.

Table (2) shows comparison between groups A and $\mathrm{B}$ regarding ascitic fluid analysis. Group A showed significantly high levels of ascitic fluid Table (2): Comparison between groups A \& B regarding ascitic fluid analysis

total leukocytic count, polymorphonuclear leukocytes and total protein $(\mathrm{P}<0.001)$ in comparison to group B.

\begin{tabular}{|l|c|c|c|c|}
\hline \multicolumn{1}{|c|}{$\begin{array}{c}\text { Variable } \\
(\text { Mean } \pm \text { SD) }\end{array}$} & $\begin{array}{c}\text { Group A } \\
(\mathbf{N = 2 5})\end{array}$ & $\begin{array}{c}\text { Group B } \\
(\mathbf{N = 2 5})\end{array}$ & $\mathbf{t}$ & $\mathbf{p}$ \\
\hline TLC (cell/mL) & $1307.5 \pm 712.3$ & $8.3 \pm 2.2$ & 9.120 & $<\mathbf{0 . 0 0 1 *}$ \\
\hline PMNL (cell/mL) & $551.3 \pm 71.8$ & $6.3 \pm 1.4$ & 37.932 & $<\mathbf{0 . 0 0 1 *}$ \\
\hline Albumin (g/dL) & $0.6 \pm 0.2$ & $0.7 \pm 0.3$ & 0.778 & 0.440 \\
\hline Total Protein (g/dL) & $2.7 \pm 0.3$ & $1.5 \pm 0.2$ & 14.266 & $<\mathbf{0 . 0 0 1 *}$ \\
\hline SAAG & $1.9 \pm 0.5$ & $2.0 \pm 0.6$ & -0.707 & 0.483 \\
\hline LDH (IU/L) & $139.2 \pm 73.1$ & $138.6 \pm 78.5$ & 0.030 & 0.976 \\
\hline Glucose (mg/dL) & $105.1 \pm 13.6$ & $116.1 \pm 31.7$ & -1.598 & 0.117 \\
\hline
\end{tabular}

*Significant

TLC: Total leukocytic count, PMNL: polymorphonuclear leukocytes, SAAG: serum-ascites albumin gradient, LDH: Lactate dehydrogenase. 
Table (3) shows that group A had significantly higher serum calprotectin and C-reactive protein levels than other groups $(\mathrm{P}<0.001)$.

Table (3): Comparison between the three studied groups regarding serum calprotectin and CRP

\begin{tabular}{|c|c|c|c|c|c|c|}
\hline Variable & $\begin{array}{c}\text { Group A } \\
(\mathrm{N}=\mathbf{2 5})\end{array}$ & $\begin{array}{c}\text { Group B } \\
(\mathrm{N}=\mathbf{2 5})\end{array}$ & $\begin{array}{c}\text { Group C } \\
(\mathrm{N}=\mathbf{2 5})\end{array}$ & $\stackrel{\wedge}{A / B}$ & $\hat{\wedge}$ & $\stackrel{\wedge}{\mathrm{B} / \mathrm{C}}$ \\
\hline $\begin{array}{l}\text { CRP }(\mathbf{m g} / \mathbf{d L}) \\
- \text { Mean } \pm \text { SD } \\
\text {-Range }\end{array}$ & $\begin{array}{l}36.7 \pm 16.6 \\
12.0-68.0\end{array}$ & $\begin{array}{l}4.7 \pm 1.6 \\
2.0-7.0\end{array}$ & $\begin{array}{l}5.0 \pm 1.5 \\
2.0-7.0\end{array}$ & $\begin{array}{c}\mathrm{t}=9.593 \\
\mathbf{p}<\mathbf{0 . 0 0 1} *\end{array}$ & $\begin{array}{c}t=9.530 \\
\mathbf{p}<\mathbf{0 . 0 0 1} *\end{array}$ & $\begin{array}{l}t=0.551 \\
p=0.584\end{array}$ \\
\hline $\begin{array}{l}\text { Calprotectin }(\mu \mathrm{g} / \mathrm{mL}) \\
\text {-Mean } \pm \text { SD } \\
\text {-Range }\end{array}$ & $\begin{array}{c}61.6 \pm 7.3 \\
47.9-73.7\end{array}$ & $\begin{array}{c}24.8 \pm 14.8 \\
8.9-46.7\end{array}$ & $\begin{array}{c}24.4 \pm 11.8 \\
6.6-39.0\end{array}$ & $\begin{array}{l}\mathrm{t}=11.364 \\
\mathbf{p}<\mathbf{0 . 0 0 1} *\end{array}$ & $\begin{array}{l}\mathrm{t}=13.431 \\
\mathbf{p}<\mathbf{0 . 0 0 1}^{*}\end{array}$ & $\begin{array}{l}\mathrm{t}=0.038 \\
\mathrm{p}=0.970\end{array}$ \\
\hline
\end{tabular}

${ }^{\wedge}$ Independent test, $*$ Significant, CRP: C-reactive protein.

Table (4) and Figure (1) show correlation between serum calprotectin and different parameters among the studied groups. There were significant positive correlations between serum calprotectin and serum WBC, CRP \& ascitic fluid TLC, PMNL and total protein among group A.

Table (4): Correlation between serum calprotectin and different parameters among the studied groups.

\begin{tabular}{|c|c|c|c|c|c|c|}
\hline \multirow{2}{*}{ Variables } & \multicolumn{2}{|c|}{ Group A (N=25) } & \multicolumn{2}{|c|}{ Group B $(N=25)$} & \multicolumn{2}{|c|}{ Group C (N=25) } \\
\hline & $\mathbf{r}^{\wedge}$ & $\mathbf{p}$ & $\mathbf{r}^{\wedge}$ & p & $\mathbf{r}^{\wedge}$ & p \\
\hline Age & -0.273 & 0.186 & 0.061 & 0.779 & -0.348 & 0.089 \\
\hline Child score & 0.246 & 0.243 & 0.290 & 0.478 & 0.045 & 0.964 \\
\hline Bilirubin & -0.026 & 0.900 & 0.183 & 0.391 & -0.127 & 0.545 \\
\hline ALT & -0.112 & 0.594 & -0.045 & 0.833 & -0.137 & 0.512 \\
\hline AST & -0.100 & 0.633 & 0.017 & 0.936 & -0.215 & 0.302 \\
\hline Serum Albumin & 0.100 & 0.634 & -0.053 & 0.804 & 0.313 & 0.128 \\
\hline INR & 0.140 & 0.504 & -0.011 & 0.961 & -0.351 & 0.085 \\
\hline Hb & 0.109 & 0.604 & -0.101 & 0.638 & -0.274 & 0.185 \\
\hline WBC & 0.969 & $<0.001 *$ & -0.023 & 0.915 & -0.197 & 0.344 \\
\hline PLT & -0.010 & 0.961 & 0.141 & 0.512 & -0.207 & 0.321 \\
\hline CRP & 0.963 & $<0.001 *$ & 0.011 & 0.960 & -0.039 & 0.855 \\
\hline AF TLC & 0.816 & $<0.001 *$ & 0.180 & 0.399 & -- & -- \\
\hline AF PMNL & 0.973 & $<0.001 *$ & -0.303 & 0.150 & -- & -- \\
\hline AF Albumin & -0.047 & 0.824 & 0.321 & 0.126 & -- & -- \\
\hline AF Total Protein & 0.519 & $0.029 *$ & -0.219 & 0.294 & -- & -- \\
\hline SAAG & 0.012 & 0.955 & -0.085 & 0.693 & -- & -- \\
\hline AF LDH & 0.080 & 0.704 & -0.013 & 0.950 & -- & -- \\
\hline AF Glucose & 0.050 & 0.812 & -0.126 & 0.559 & -- & -- \\
\hline
\end{tabular}

${ }^{\wedge}$ Spearman correlation, $*$ Significant.

ALT: Alanine aminotransferase, AST: Aspartate aminotransferase, INR: International normalization ratio, HB: Haemoglobin, WBC: White blood cells, PLT: Platelets, CRP: C-reactive protein, AF: Ascitic fluid, TLC: Total leukocytic count, PMNL: polymorphonuclear leukocytes, SAAG: serum-ascites albumin gradient, LDH: Lactate dehydrogenase. 


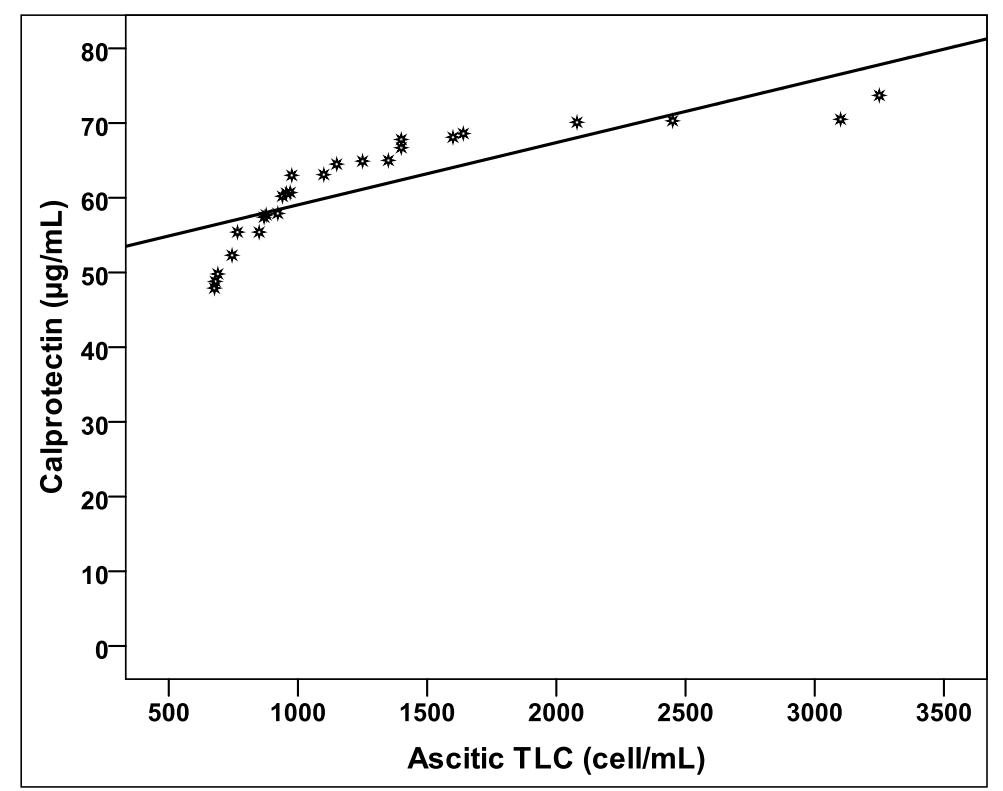

Figure (1): Correlation between serum calprotectin and ascitic fluid TLC among group A. There was a significant positive linear correlation $\left(\mathrm{r}^{\wedge}=0.816, \mathrm{p}<0.001\right)$.

Table (5) and Figure (2) show that serum calprotectin and CRP had the most significant diagnostic performance in detection of spontaneous bacterial peritonitis (SBP) (AUC $=0.976$ and 1.000 respectively, $\mathrm{P}<0.001$ ).
On comparing the AUC of ROC curve of serum $\mathrm{CRP}$ and serum calprotectin in differentiating between group A (with SBP) and group B (with sterile cirrhotic ascites), it was found that $\mathrm{P}$ value was non-significant $(\mathrm{P}=0.242)$.

Table (5): Performance of serum WBC, CRP and calprotectin in detection of SBP.

\begin{tabular}{|c|c|c|c|c|}
\hline Variable & AUC & SE & $\mathbf{P}$ & 95\% CI \\
\hline Calprotectin & 0.976 & 0.012 & $<0.001 *$ & $0.500-1.000$ \\
\hline CRP & 1.000 & 0.000 & $<0.001 *$ & $1.000-1.000$ \\
\hline WBC & 0.625 & 0.080 & 0.130 & $0.500-0.782$ \\
\hline \multicolumn{5}{|c|}{ Comparison between AUCs\# } \\
\hline & CRP & WBC & & \\
\hline Calprotectin & 0.242 & $<0.001^{*}$ & & \\
\hline CRP & -- & $<0.001^{*}$ & & \\
\hline
\end{tabular}

SBP: spontaneous bacterial peritonitis, CRP: C-reactive protein, WBC: White blood cells, AUC: Area under curve, SE: Standard error, CI: Confidence interval, \#DeLong test, *Significant. 


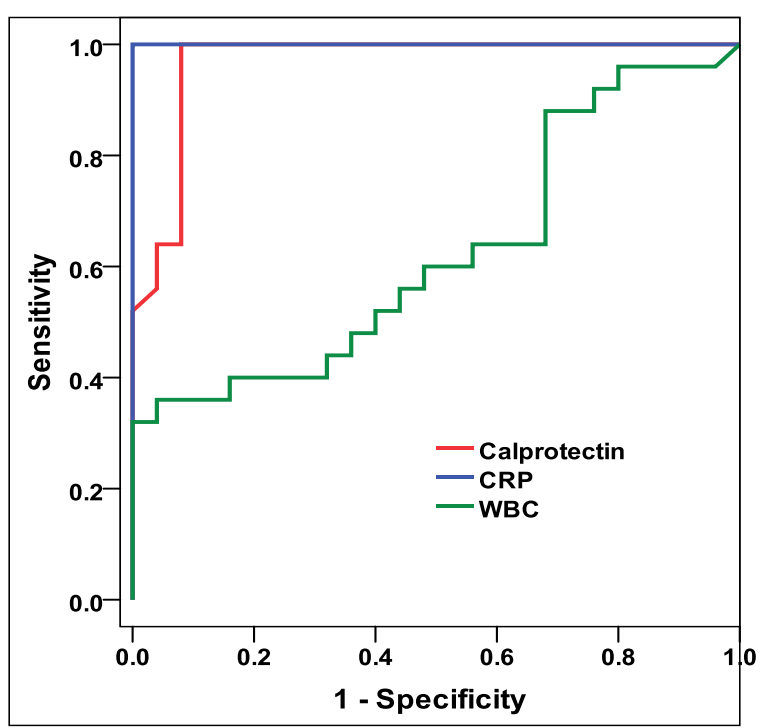

Figure (2): ROC curve showing the diagnostic performance of serum WBC, CRP and calprotectin in detection of SBP.

In differentiation between groups $\mathrm{A} \& \mathrm{~B}$, a cut-off level of serum calprotectin $\geq 46.0 \mu \mathrm{g} / \mathrm{mL}$ showed a sensitivity of $100 \%$, specificity $92 \%$ and diagnostic accuracy $96 \%$; while that of $C R P \geq 9.0$ $\mathrm{mg} / \mathrm{dL}$ showed a sensitivity of $100 \%$, specificity $100 \%$ and diagnostic accuracy $100 \%$. Thus, serum calprotectin $\geq 46.0$ and $\mathrm{CRP} \geq 9.0$ were excellent parameters in detection of SBP (Table 6).

Table (6): Value of suggested cut-off levels of serum calprotectin and CRP in detection of SBP

\begin{tabular}{|l|c|c|c|}
\hline Character & Value & \multicolumn{2}{|c|}{$95 \%$ CI } \\
\hline Calprotectin $\geq \mathbf{4 6 . 0}(\boldsymbol{\mu g} / \mathbf{m L})$ & $100.0 \%$ & $100.0 \%$ & $100.0 \%$ \\
\hline Sensitivity & $92.0 \%$ & $90.0 \%$ & $92.5 \%$ \\
\hline Specificity & 12.5 & 52.4 & 800.4 \\
\hline Positive likelihood ratio (LR+) & 0.0 & 0.0 & 0.0 \\
\hline Negative likelihood ratio (LR-) & $96.0 \%$ & $94.9 \%$ & $96.3 \%$ \\
\hline Diagnostic accuracy (DA) & & & \\
\hline CRP $\geq \mathbf{9 . 0}(\mathbf{m g} / \mathbf{d L})$ & $100.0 \%$ & $100.0 \%$ & $100.0 \%$ \\
\hline Sensitivity & $100.0 \%$ & $100.0 \%$ & $100.0 \%$ \\
\hline Specificity & -- & -- & -- \\
\hline Positive likelihood ratio (LR+) & 0.0 & 0.0 & 0.0 \\
\hline Negative likelihood ratio (LR-) & $100.0 \%$ & $100.0 \%$ & $100.0 \%$ \\
\hline Diagnostic accuracy (DA) & & & \\
\hline
\end{tabular}

-- Cannot be calculated.

\section{DISCUSSION}

The diagnosis of SBP is still based on diagnostic paracentesis which is an invasive manoeuvre with some complications like ascitic fluid leakage from the point of needle insertion into the skin, bleeding, and infection ${ }^{(12)}$. In addition, the ascitic fluid culture takes a long time and may be negative in the entity of culture-negative neutrocytic ascites (CNNA) ${ }^{(7)}$. 
Therefore, there is a need for other non-invasive rapid diagnostic tools. Any serum biological marker that could strongly predict SBP may obviate the need for paracentesis while increasing the patient's chance of survival by expediting the diagnosis and treatment of SBP ${ }^{(13)}$.

C-reactive protein (CRP) is an acute phase reactant which binds to different substrates. It activates complements, takes part in cytokine secretion, and increases the phagocytosis of leukocytes. CRP has been previously reported to be a reliable predictor of SBP and an index of improvement ${ }^{(14)}$.

Calprotectin is an acute phase reactant secreted predominantly by the neutrophils and plays a vital role in infection and inflammation. It serves as a potential diagnostic marker for various inflammatory diseases ${ }^{(15)}$. It has been previously reported that the measurement of fecal calprotectin concentration could serve as a screening tool for SBP ${ }^{(11)}$. However, the use of serum calprotectin in diagnosis of SBP remains unexplored.

This study aimed at evaluating the role of serum calprotectin as a non-invasive diagnostic marker for SBP in Egyptian cirrhotic patients in comparison to CRP.

Regarding the ascitic fluid cell count in the current study, there were higher levels of ascitic TLC and PMNL count in SBP group in comparison to the group with sterile cirrhotic ascites, and this result is in agreement with Girón-González et al. ${ }^{(16)}$, Yildirim et al. ${ }^{(17)}$ and Abdel-Razik et al. ${ }^{(18)}$.

As regards ascitic fluid total protein, it was significantly higher in SBP group than in sterile cirrhotic ascites group $(\mathrm{P}<0.001)$. This result is in agreement with Reginato et al. ${ }^{(19)}$.

Regarding the SAAG value, it was higher than 1.1 in SBP group with no statistically significant difference when compared to sterile cirrhotic ascites group, and this was in agreement with Salama et al. ${ }^{(20)}$. This finding can be explained by the study of Desai et al. (21), who denoted that regardless the severity of liver disease, those with lower ascitic albumin and higher SAAG levels are less likely to have a satisfactory immune response with poor clearance of infection.

In this study, there was no significant difference between SBP group and the group with sterile cirrhotic ascites as regards the ascitic fluid glucose, and this is in agreement with Bibi et al. (22).

Regarding the relation between occurrence of SBP and Child-Pugh class, we found that $92 \%$ of patients with SBP were in Child C class compared to $76 \%$ of patients with sterile cirrhotic ascites, and this result is close to Abdel-Razik et al. ${ }^{(18)}$ who found that about $75 \%$ of the patients who developed SBP were in Child C class, with the remainder were in class $B$.

In the current study, we found significantly higher levels of serum calprotectin in SBP patients than in the other two groups.

Ali et al. ${ }^{(23)}$ found that ascitic calprotectin level showed significantly higher value in patients with SBP than those without SBP.

Lutz et al. ${ }^{(24)}$ also reported that ascitic calprotectin could be used as a test for SBP, but test performance was further improved by calculating the ratio between ascitic calprotectin and ascitic total protein. They also reported that this ratio could provide prognostic information on shortterm survival of SBP patients.

Gundling et al. (11) found also that fecal calprotectin levels were elevated significantly in cirrhotic patients with SBP in comparison to those without SBP.

In our study, we found a significant positive correlation between higher serum calprotectin level and elevated white blood cell count among SBP patients. This is consistent with Abdel-Razik, et al. ${ }^{(25)}$. This finding can be explained by the fact that serum calprotectin is an acute phase inflammatory reaction protein exerting regulatory, antimicrobial and anti-proliferative functions ${ }^{(10)}$.

In this study, we found that high serum calprotectin level was significantly correlated with high ascitic fluid TLC and PMNL levels in SBP group. Also, Burri et al. ${ }^{(6)}$, Abdel-Razik et al. ${ }^{(18)}$, and Ali et al. ${ }^{(23)}$, found that ascitic calprotectin 
levels were correlated well and reliably with ascitic PMNL counts, and the samples with $\mathrm{PMNL}>250 / \mu \mathrm{L}$ also had higher ascitic calprotectin levels than the samples with PMNL $\leq$ $250 / \mu \mathrm{L}$ in their studies.

The correlation between high serum \& ascitic calprotectin with high ascitic TLC and PMNL levels can be explained by the study of Soyfoo et al. ${ }^{(9)}$, who denoted that calprotectin presence in body fluids is proportional to the influx of neutrophils.

In our study, there was a significant positive correlation between serum calprotectin and CRP, and this result is in agreement with Rizk et al. ${ }^{(26)}$. We found also that both serum calprotectin and CRP were significantly higher in group A (with SBP) than group B (with sterile cirrhotic ascites) $(\mathrm{P}<0.001)$.

In the current study, a cut off level of $\geq 9.0$ $(\mathrm{mg} / \mathrm{dL})$ for serum CRP in detecting SBP showed a highly significant diagnostic performance with AUC 1.000 (P <0.001), sensitivity $100 \%$ and specificity $100 \%$. Rizk et al. ${ }^{(26)}$ reported that at a cutoff value of $30 \mathrm{mg} / \mathrm{dL}$, CRP had $96 \%$ specificity and $90 \%$ sensitivity for detecting SBP with $\mathrm{AUC}=0.91$.

On the other hand, using a cut off value $\geq 46.0$ $(\mu \mathrm{g} / \mathrm{mL})$ for serum calprotectin in detecting SBP in our study revealed that serum calprotectin had a highly significant diagnostic performance with AUC 0.976 ( $\mathrm{P}<0.001)$, sensitivity $100 \%$ and specificity $92 \%$.

Rizk et al. ${ }^{(26)}$ demonstrated that at a cut off value of $270 \mathrm{mg} / \mathrm{dl}$, ascitic fluid calprotectin had $86 \%$ specificity and $97.5 \%$ sensitivity for detecting $\mathrm{SBP}$ with $\mathrm{AUC}=0.924$. Whereas Lutz et al. ${ }^{(24)}$ found that the ratio of ascitic calprotectin to ascitic total protein with a cut-off value of 5.24 achieved a sensitivity of $90 \%$ and specificity of $81 \%$ in detecting SBP with AUC= $0.92(\mathrm{p}<0.001)$.

On comparing the AUC of ROC curve of serum $\mathrm{CRP}$ and serum calprotectin in differentiating between group A (with SBP) and group B (with sterile cirrhotic ascites), it was found that $\mathrm{P}$ value was non-significant $(\mathrm{P}=0.242)$.
The previous findings indicate that serum calprotectin in combination with serum CRP correlate well and reliably with ascitic PMNL count in patients with SBP. Indeed, using serum calprotectin together with serum CRP is superior to the using of one of them alone and may serve as a surrogate marker for ascitic PMNL count and could be amenable to routine SBP screening.

\section{CONCLUSION}

Serum calprotectin in combination with serum CRP correlated well with ascitic PMNL count in patients with SBP. Using both markers together is superior to the using of one of them alone and may be useful for non-invasive diagnosis of SBP.

Conflict-of-interest: None of the authors have any conflicts of interests and no financial disclosure

\section{REFERENCES}

1. Guarner C and Runyon B (2005): Spontaneous bacterial peritonitis: Pathogenesis, diagnosis and treatment. J. Gastroenterol., 3: 311-328.

2. Soriano G, Castellote J, Alvarez C, et al., (2010): Secondary bacterial peritonitis in cirrhosis: a retrospective study of clinical and analytical characteristics, diagnosis and management. J Hepatol; 52:39.

3. Bonnel AR, Bunchorntavakul C, Reddy $\mathrm{KR}$, et al., (2011): Immune dysfunction and infections in patients with cirrhosis. Clin Gastroenterol Hepatol 2011; 9: 727738.

4. Singal AK, Salameh H, Kamath PS, et al., (2014): Prevalence and in-hospital mortality trends of infections among patients with cirrhosis: a nationwide study of hospitalised patients in the United States. Aliment Pharmacol Ther 2014; 40: 105-112.

5. Lee JM, Han KH, Ahn SH, et al., (2009): Ascites and spontaneous bacterial 
peritonitis J Gastroenterology Hepatolgy 24(9):1494-503.

6. Burri E, Schulte F, Muser J, et al., (2013): Measurement of calprotectin in ascitic fluid to identify elevated polymorphonuclear cell count. World J Gastroenterol; 19(13):2028-36.

7. Justin H , Helen W , Kevin J , et al., (2012): Identification of Bacterial Pathogens in Ascitic Fluids from Patients with Suspected Spontaneous Bacterial Peritonitis by Use of Broad-Range PCR (16S PCR) Coupled with High-Resolution Melt Analysis. J Clin Microbiol. 50(7):2428-32.

8. Van Rheenen PF, Van de Vijver E, Fidler V, et al., (2010): Faecal calprotectin for screening of patients with suspected inflammatory bowel disease: diagnostic meta-analysis. BMJ. 2010; 341: c3369.

9. Soyfoo MS., Roth J., Vogl T, et al., (2009): Phagocyte specific S100A8/A9 protein levels during disease exacerbations and infections in systemic lupus erythematosus. J Rheumatol; 36: 21902194

10. Yui S, Nakatani Y, Mikami M, et al., (2003): Calprotectin (S100A8/S100A9), an inflammatory protein complex from neutrophils with a broad apoptosisinducing activity. Biol. Pharm. Bull. 26, 753-760.

11. Gundling F, Schmidtler F, Hapfelmeier A, et al.,(2011): Fecal calprotectin is a useful screening parameter for hepatic encephalopathy and spontaneous bacterial peritonitis in cirrhosis. Liver Int. 2011 Oct;31(9):1406-15.

12. De Gottardi A, Thevenot T, Spahr L, et al., (2009): Risk of complications after abdominal paracentesis in cirrhotic patients: A prospective study. Clin Gastroenterol Hepatol.; 7:906-9.

13. Asadi Gharabaghi M, Allameh SF, Foroutan $\mathrm{H}$ et al., (2015):
Blood Procalcitonin Predicts Spontaneous Bacterial Peritonitis in Patients with Cirrho sis and Ascites. Middle East J Dig Dis.; 7: 189-90.

14. Preto-Zamperlini M, Farhat SC, Perondi MB, et al., (2014): Elevated C-reactive protein and spontaneous bacterial peritonitis in children with chronic liver disease and ascites. $J$ Pediatr Gastroenterol Nutr.; 58(1):96-8.

15. Dhas D, Bhat B, and Gane D (2012). Role of Calprotectin in Infection and Inflammation. Curr Pediatr Res; 16 (2): 83-94.

16. Girón-González JA, Rodríguez-Ramos C, Elvira J, et al., (2001): Serial analysis of serum and ascitic fluid levels of soluble adhesion molecules and chemokines in patients with spontaneous bacterial peritonitis. Clin. Exp. Immunol. 123 (1): $56-61$.

17. Yildirim B, Sari R, and Isci N (2005): Patients with spontaneous bacterial peritonitis, and malignant and cirrhotic ascites. J Natl Med Assoc.; 97(2): 276280.

18. Abdel-Razik A, Mousa N, Elhammady D, et al., (2015): Ascitic Fluid Calprotectin and Serum Procalcitonin as Accurate Diagnostic Markers for Spontaneous Bacterial Peritonitis. Gut Liver. doi: 10.5009/gnl15120 [Epub ahead of print].

19. Reginato TJ, Oliveira MJ, Moreira LC, et al., (2011): Characteristics of ascitic fluid from patients with suspected spontaneous bacterial peritonitis in emergency units at a tertiary hospital. Sao Paulo Med J.; 129(5): 315-9.

20. Salama MK, Sabry D, Al-Ghussein MA, et al., (2014): Molecular detection of monocyte chemotactic protein-1 polymorphism in spontaneous bacterial peritonitis patients. World $J$ Gastroenterol.; 20(33): 11793-11799 
21. Desai A, Reau N, Reddy KG, et al., (2012): Persistent spontaneous bacterial peritonitis: a common complication in patients with spontaneous bacterial peritonitis and a high score in the model for end-stage liver disease. Therap $A d v$ Gastroenterol., 5(5): 275-283.

22. Bibi S, Ahmed W, Arif, et al., (2015): Clinical, laboratory and bacterial profile of Spontaneous Bacterial Peritonitis in Chronic Liver Disease patients. $J$ Coll Physicians Surg Pak. 25(2):95-9. doi: 02.2015/JCPSP.9599

23. Ali AG, Ahmed NS, Hasan SM, et al., (2013): Calprotectin measurement in ascitic fluid: a new test for the rapid diagnosis of spontaneous bacterial peritonitis. Med $J$ Cairo Univ 2013; 81:53-56.

24. Lutz P, Pfarr K, Nischalke HD, et al., (2015): The ratio of calprotectin to total protein as a diagnostic and prognostic marker for spontaneous bacterial peritonitis in patients with liver cirrhosis and ascites. Clin Chem Lab Med.; 53(12):2031-9.

25. Abdel-Razik A, Eldars W, Rizk E, et al. (2014): Platelet indices and inflammatory markers as diagnostic predictors for ascitic fluid infection. Eur J Gastroenterol Hepatol.; 26(12):1342-7.

26. Rizk E, Elzehery R, Zakaria S, et al., (2014): Ascitic Fluid Calprotectin and Serum C-Reactive Protein as Diagnostic Markers for Spontaneous Bacterial Peritonitis. Afro-Egypt J Infect Endem Dis; 4(3): 117-125. 